Animal Health Research Institute (Zagazig branch)

\title{
IMPROVEMENT OF THE FERETILITY AND SOME BIOCHEMICAL EFFECTS OF AFLATOXIN ON MALE RABBIT BY GENSING
}

(With 4 Tables and 4 Figures)

\author{
By \\ E.E. EMAM and SHAHIRA H.M. HUSSEIN \\ (Received at 1/10/2007)
}

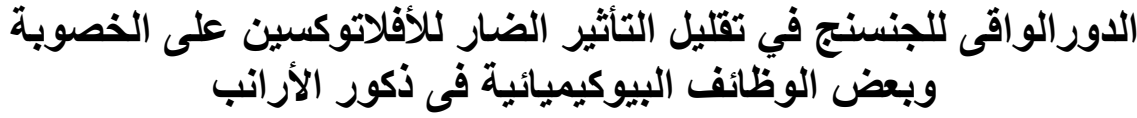

السبي السيل إمام حسن ، شعيرة حنفي محود حسين

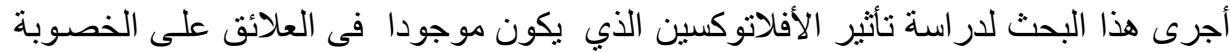

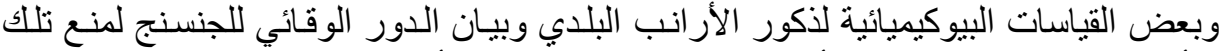

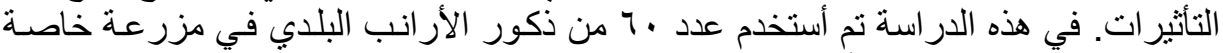

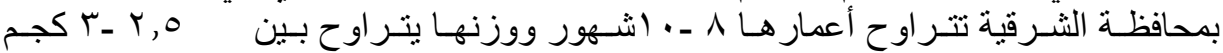

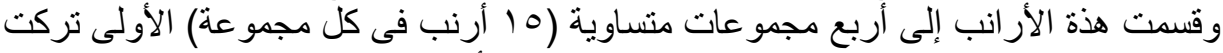

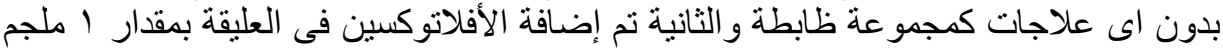

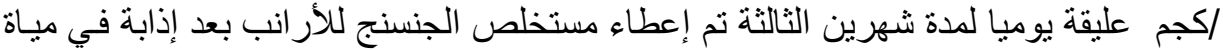

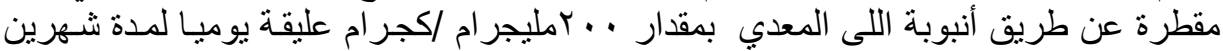

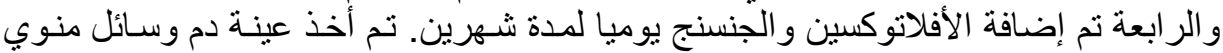

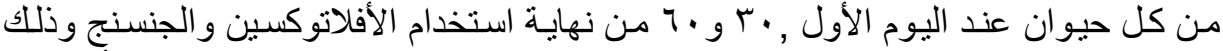

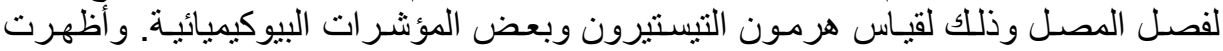

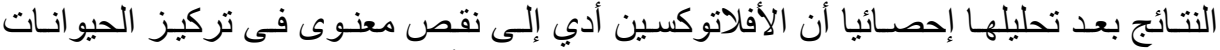

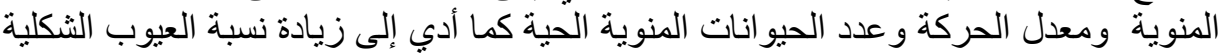

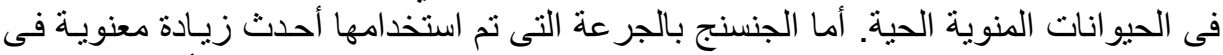

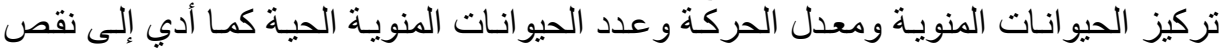

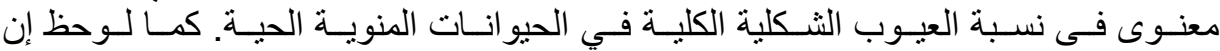

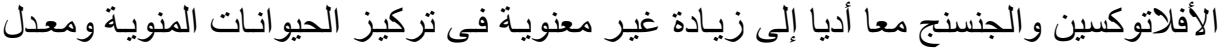

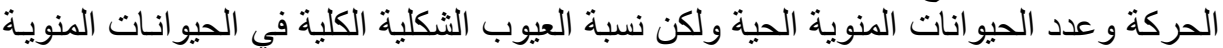

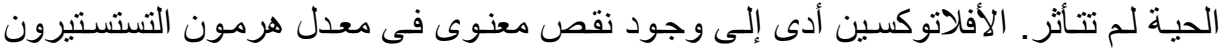

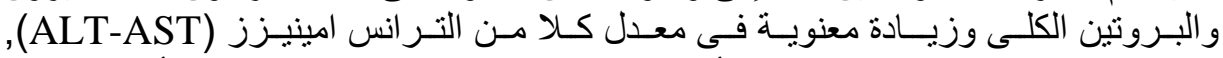

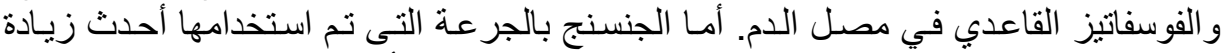

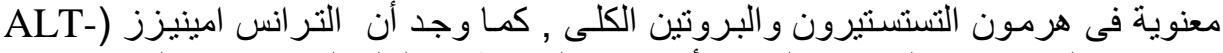

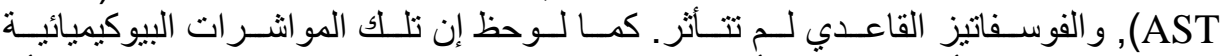

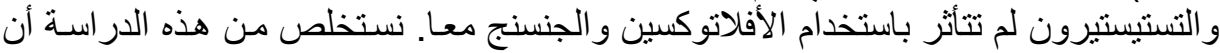




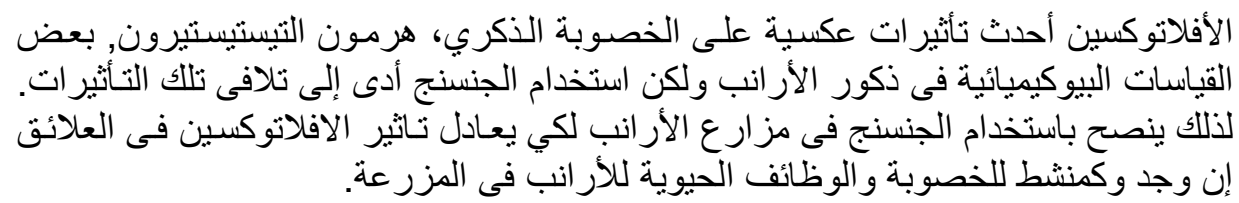

\section{SUMMARY}

The present study was carried out to investigate the effect of aflatoxin contamin-ated feed on male fertility and some biochemical parameters in male rabbits and modulating this effect by using gensing. A total 60 of apparently healthy adult male baladi rabbits (8-10 month of age) and $2.5-3 \mathrm{~kg}$ b.wt., were divided into four equal groups, $1^{\text {st }}$ group was left without treatment as control, $2^{\text {nd }}$ group was fed on a ration containing 1 $\mathrm{mg}$ aflatoxin $/ \mathrm{kg}$ for 60 successive days, $3^{\text {rd }}$ group received $200 \mathrm{mg} / \mathrm{kg}$ body weight of gensing extract dissolved in saline solution orally through mouth tube for 60 successive days and $4^{\text {th }}$ group was fed a ration containing $1 \mathrm{mg}$ aflatoxin $/ \mathrm{kg}$ and received $200 \mathrm{mg} / \mathrm{kg}$ by using mouth tube for 60 successive days. Five rabbits from each groups were slaughtered at $1^{\text {st }}, 30^{\text {th }}$ and $60^{\text {th }}$ days post medication. Blood and semen samples were collected from control and treated rabbits.Blood samples were used for biochemical analysis. Semen samples were collected from tail of the epididymis to evaluate semen character. Aflatoxin elucidated significant reduction on sperm cells concentration, progressive motility and live sperm but increased total abnormality percent at $1^{\text {st }}$ and $30^{\text {th }}$ days post aflatoxin medication. Gensing induced significant increase in sperm cells concentration, progressive motility, live sperm and decreased total abnormality percent at $1^{\text {st }}$ and $30^{\text {th }}$ days post treatment. Rabbits received both aflatoxin and gensing induced non significant effect on sperm cells concentration, progressive motility, live sperm and total abnormality percent. Aflatoxin induced significant decrease in testosterone hormone level, weight of secondary sex organs (testis, seminal vesicle and prostate gland), total protein and significant elevation in serum transaminases (AST-ALT) and alkaline phosphatas at $1^{\text {st }}$ and $30^{\text {th }}$ days post feeding on aflatoxin.Gensing induced significant increase in the level of serum total protein, testosterone hormone but ALT, AST and alkaline phosphatas non significantly effect. Aflatoxin and gensing induced non significant effect in the above biochemical parameters. It could be concluded that aflatoxin induced many reversible alteration in male fertility, hormonal and some biochemical parameters as they returned to their normal values $60^{\text {th }}$ day after stoping aflatoxin 
addition. Gensing minimize or reduce the alteration in fertility and biochemical changes induced by aflatoxin.

Key words: Rabbit, feretility, aflatoxin

\section{INTRODUCTION}

Aflatoxins are toxic metabolites produced by fungi of Aspergillus species. They are produced by many strains of Aspergillus flavus, Aspergillus parasiticus and Penicillin puberulum (Peterson, et al., 2001). There are four generally aflatoxin B1, B2, G1 and G2 Aflatoxin B1 is the more toxic. (Ciegler and Bennet, 1980). The susceptibilily of animals to aflatoxins varies considerably, depending on sex, age, species and nutrition (Eaton and Groopman, 1994). Aflatoxin also induce anemia,poor digestion,inhibition of protein synthesis,lipid peroxidation and oxidative DNA damage (Verma and Nair, 2001). Aflatoxicosis reduce the male fertility (Chao, 1991).

Many studies were attempeted to reduce aflatoxin in the contaminated food by using numerous physical, chemical and/or biological technique (Samarajeewa et al., 1991). Some herbal food supplements were found to reduce the toxic effect of aflatoxin through its antioxidant effect (El-Seidy et al., 2002). Also some medicinal herbs has a protective action against free radical (Ahmed et al., 2000).

Panax gensing is one of the most valued medicinal herbaceous plant belonged to family Araliaceae (Kamel and Hoda, 2006). It is herbal root, has a wide pharmacological action in the clinical practice (Chong and Oberholzer, 1989). This plant contain many valuable ingredients such as saponins (known as panaxosides or gensingosid, vitamin A, B6, mineral as zinc, antioxidant, peptides, fatty acids, polysaccharide, alcohol and cholestryl ester transfer protein inhibitors (Huang, 1999). The various forms of gensing appear to be non toxic (Hess et al., 1982). Gensing decreases nitric acid content and nitric oxide synthase activity (play a role in accelerating senility) in the cerebral cortex in rats (Li et al., 1997). Gensing improves the survival rate and sperm quality in guinea pigs (Kim et al., 2004).

The objective of the present work was to evaluate the effect of dietary suppl-ementation of aflatoxin on the male fertility and some biochemical parameters in rabbit and modulating this effect by using gensing.

\section{MATERIALS and METHODS}

\section{1- Drug:-}


Gensing Extract (Korean red Gensing extract) was obtained from Pharco Pharmaceuticals, Alexandria, Egypt in capsules and each capsule contain $100 \mathrm{mg}$ of gensing extract.

\section{2-Animals:-}

The present investigation was carried out on sixty male rabbits 8 months old and about 2.5-3 kg body weight. Rabbits were obtained from private rabbit farm in Sharkia Province. Rabbits were housed under hygienic condition, feed comm-ercial pellets (Table 1) and watered adlibitum during the experimental period.

Table 1: Ingredients of experimental diet.

\begin{tabular}{|c|c|}
\hline Component & $\%$ \\
\hline Barly & 25 \\
\hline Bran & 25 \\
\hline Soya bean meal 44 \% protein & 3 \\
\hline Sun flower meal 24 \% protein & 24.55 \\
\hline Berseem hay & 15 \\
\hline Soya oil & 3 \\
\hline Bone meal & 2 \\
\hline Lime stone & 1 \\
\hline Sodium chloride & 1 \\
\hline Methionine & 0.15 \\
\hline Vitamins/ minerals premix & 0.3 \\
\hline
\end{tabular}

\section{3-Experimental design:}

Rabbits were divided into four equal groups (15 rabbits each). First group left without treatment as control group, $2^{\text {nd }}$ group was fed on a ration containing $1 \mathrm{mg}$ aflatoxins / $\mathrm{kg}$ ration for 60 successive days, $3^{\text {rd }}$ group received $200 \mathrm{mg}$ of gensing extract $/ \mathrm{kg}$ body weight extract, that dissolved in saline solution then by using mouth tube introduce the extract daily for 60 days (Choi et al., 1999), and $4^{\text {th }}$ group was fed on a ration containing $1 \mathrm{mg}$ aflatoxins $/ \mathrm{kg}$ ration and $200 \mathrm{mg}$ of gensing extract / kg b.wt.for 60 successive days. Five rabbits from each groups were slaughtered at $1^{\text {st }}, 30^{\text {th }}$ and $60^{\text {th }}$ days post medication. Blood samples from control and treated rabbits were taken for obtained clear serum for biochemical analysis and Semen sample were taken from tail of the epididymis to evaluate semen characters.

\section{A) Examination of epididymal sperm}

After rabbits have been slaughtered the epididymal content of each rabbit was collected and squeezed gently in sterile watch glass containing $1 \mathrm{ml}$ sodium citrate solution $2.9 \%$ to estimate the percentage of progressive motility, sperm cell concentration / mm3,alive sperm 
percent and percentage of total sperm abnormalities according to the method described by Bearden and Flaquary (1980).

\section{B) Blood samples hormonal and biochemical assays}

One blood samples from control and treated rabbits were taken at $1^{\text {st }}, 30^{\text {th }}$ and $60^{\text {th }}$ days post medication and collected in test tubes during animal slaughtering and left to clot at room temperature then centrifugated for about ten minutes at 3000 r.p.m to obtain clear serum for determination of testosterone hormone by radioimmunoassay according to the method described by Wilson and Foster (1992), aspartate aminotransferase (AST), alanine aminotransferase (ALT) activities according to the methods described by Reitman and Frankel (1957), serum alkaline phosphatase according to Kind and King(1954) and total protein according to Doumas (1975).

\section{C) Sex organs weight}

Following slaughtering of the male rabbits testis and secondary sex organs (seminal vesicle and prostate gland) were dissected out and weighted at $1^{\text {st }}, 30^{\text {th }}$ and $60^{\text {th }}$ days post medication.

\section{4-Statistical analysis:-}

The obtained results were statistically by Student t test were explained by Petrie and Watson (1999)

\section{RESULTS}

The obtained results were tabulated in Tables 2, 3, 4 and Fig A, $\mathrm{B}, \mathrm{C}$ and $\mathrm{D}$

Table 2: Effect of aflatoxin (1 $\mathrm{mg} / \mathrm{kg} \mathrm{BW})$ gensing $(200 \mathrm{mg} / \mathrm{kg} \mathrm{BW})$ either alone or together on sperm cell concentration $(x 106 \mathrm{spz} / \mathrm{ml})$, sperm motility(\%), live sperm (\%) total sperm abnormality (\%) and Testosterone hormone $(\mathrm{ng} / \mathrm{ml})$ at 1st, 30th and 60th days post medication for two months in male baladi rabbits $(n=5)$

\begin{tabular}{|c|c|c|c|c|c|c|c|c|c|c|}
\hline \multirow[t]{2}{*}{ parameter } & \multirow{2}{*}{$\begin{array}{l}\text { Healthy } \\
\text { rabbit } \\
\text { (control }\end{array}$} & \multicolumn{3}{|c|}{$1^{\text {st }}$ days } & \multicolumn{3}{|c|}{$30^{\text {th }}$ days } & \multicolumn{3}{|c|}{$60^{\text {th }}$ days } \\
\hline & & $\mathrm{AF}$ & GE & $\begin{array}{c}\mathrm{AF}+ \\
\mathrm{GE}\end{array}$ & $\mathrm{AF}$ & GE & $\begin{array}{c}\mathrm{AF}+ \\
\mathrm{GE}\end{array}$ & $\mathrm{AF}$ & GE & $\begin{array}{c}\mathrm{AF}+ \\
\mathrm{GE}\end{array}$ \\
\hline $\begin{array}{l}\text { Sprem cell } \\
\text { concentration }\end{array}$ & $\begin{array}{c}2.95 \pm \\
0.28\end{array}$ & $\begin{array}{l}1.83 \pm \\
0.16 * *\end{array}$ & $\begin{array}{l}3.92 \pm \\
0.19^{*}\end{array}$ & $\begin{array}{l}3.16 \pm \\
0.23\end{array}$ & $\begin{array}{l}2.06 \pm \\
0.12^{*}\end{array}$ & $\begin{array}{l}3.71 \pm \\
0.04^{*}\end{array}$ & $\begin{array}{l}3.04 \pm \\
0.16\end{array}$ & $\begin{array}{c}2.53 \pm \\
0.18\end{array}$ & $\begin{array}{c}3.12 \pm \\
0.23\end{array}$ & $\begin{array}{c}2.98 \pm \\
0.17\end{array}$ \\
\hline $\begin{array}{c}\text { Sperm } \\
\text { motility }\end{array}$ & $\begin{array}{c}82.73 \pm \\
1.83\end{array}$ & $\begin{array}{l}70.31 \pm \\
2.40 * *\end{array}$ & $\begin{array}{c}90.52 \pm \\
1.76^{*}\end{array}$ & $\begin{array}{c}76.90 \pm \\
1.73\end{array}$ & $\begin{array}{c}75.61 \pm \\
1.93^{*}\end{array}$ & $\begin{array}{c}88.70 \pm \\
1.72^{*}\end{array}$ & $\begin{array}{c}78.52 \pm \\
1.96\end{array}$ & $\begin{array}{c}79.63 \\
\pm \\
1.65\end{array}$ & $\begin{array}{c}83.71 \pm \\
1.98\end{array}$ & $\begin{array}{c}80.25 \pm \\
1.47\end{array}$ \\
\hline $\begin{array}{l}\text { Live } \\
\text { Sperm }\end{array}$ & $\begin{array}{c}85.23 \pm \\
1.53\end{array}$ & $\begin{array}{l}70.12 \pm \\
3.20 * *\end{array}$ & $\begin{array}{c}91.32 \pm \\
1.36^{*}\end{array}$ & $\begin{array}{c}83.0 \pm \\
1.46\end{array}$ & $\begin{array}{c}78.16 \pm \\
1.99^{*}\end{array}$ & $\begin{array}{c}89.15 \pm \\
0.86^{*}\end{array}$ & $\begin{array}{c}84.20 \pm \\
1.31\end{array}$ & $\begin{array}{c}82.92 \\
\pm \\
1.59\end{array}$ & $\begin{array}{c}85.13 \pm \\
1.26\end{array}$ & $\begin{array}{c}85.10 \pm \\
1.43\end{array}$ \\
\hline $\begin{array}{c}\text { Total } \\
\text { Abnormality }\end{array}$ & $\begin{array}{c}12.31 \pm \\
0.32\end{array}$ & $\begin{array}{l}17.42 \pm \\
1.37 * *\end{array}$ & $\begin{array}{l}9.16 \pm \\
0.22 *\end{array}$ & $\begin{array}{c}13.27 \pm \\
0.68\end{array}$ & $\begin{array}{c}15.03 \pm \\
0.42\end{array}$ & $\begin{array}{c}10.36 \pm \\
0.28\end{array}$ & $\begin{array}{c}12.59 \pm \\
0.68\end{array}$ & $\begin{array}{c}13.05 \\
\pm \\
0.82\end{array}$ & $\begin{array}{c}11.63 \pm \\
0.73\end{array}$ & $\begin{array}{c}12.05 \pm \\
0.93\end{array}$ \\
\hline Testosterone & $\begin{array}{c}3.13 \pm \\
0.53\end{array}$ & $\begin{array}{c}1.20 \pm \\
0.14 * *\end{array}$ & $\begin{array}{c}5.26 \pm \\
0.16^{* * *}\end{array}$ & $\begin{array}{c}3.60 \pm \\
0.24\end{array}$ & $\begin{array}{l}2.02 \pm \\
0.25^{*}\end{array}$ & $\begin{array}{l}4.49 \pm \\
0.13^{*}\end{array}$ & $\begin{array}{l}3.3 \pm \\
0.32\end{array}$ & $\begin{array}{c}2.92 \pm \\
0.37\end{array}$ & $\begin{array}{c}3.06 \pm \\
0.42\end{array}$ & $\begin{array}{c}4.32 \pm \\
0.26\end{array}$ \\
\hline
\end{tabular}

* Significant at $\mathrm{P}<0.05$

** Significant at $\mathrm{P}<0.01$

Table 3: Effect of aflatoxin $(1 \mathrm{mg} / \mathrm{kg} \mathrm{BW})$ gensing $(200 \mathrm{mg} / \mathrm{kg} \mathrm{BW})$ 
either alone or together on weight of testis (gm), seminal vesicle (gm) and prostate gland (gm) at 1st, 30th and 60 th days post medication for two months in male baladi rabbits $(\mathrm{n}=5)$

\begin{tabular}{|c|c|c|c|c|c|c|c|c|c|c|}
\hline \multirow{2}{*}{ Parameter } & \multirow{2}{*}{$\begin{array}{c}\text { Healthy } \\
\text { rabbit }\end{array}$} & \multicolumn{3}{|c|}{$1^{\text {st }}$ days } & \multicolumn{3}{|c|}{$30^{\text {th }}$ days } & \multicolumn{3}{|c|}{$60^{\text {th }}$ days } \\
\cline { 3 - 12 } & & AF & GE & AF+GE & AF & GE & AF+GE & AF & GE & AF+GE \\
\hline Testis & $2.37 \pm$ & $2.02 \pm$ & $2.09 \pm$ & $2.23 \pm$ & $2.61 \pm$ & $2.69 \pm$ & $2.9 \pm$ & $2.31 \pm$ & $2.39 \pm$ & $2.35 \pm$ \\
& 0.21 & 0.19 & 0.21 & 0.25 & 0.19 & 0.14 & 0.19 & 0.25 & 0.19 & 0.17 \\
\hline Seminal & $1.92 \pm$ & $1.78 \pm$ & $1.83 \pm$ & $1.89 \pm$ & $2.08 \pm$ & $2.12 \pm$ & $2.1 \pm$ & $1.85 \pm$ & $1.88 \pm$ & $1.90 \pm$ \\
vesicle & 0.21 & 0.24 & 0.19 & 0.22 & 0.41 & 0.38 & 0.21 & 0.25 & 0.22 & 0.18 \\
\hline Prostate & $0.56 \pm$ & $0.47 \pm$ & $0.53 \pm$ & $0.58 \pm$ & $0.59 \pm$ & $0.57 \pm$ & $0.5 \pm$ & $0.51 \pm$ & $0.53 \pm$ & $0.52 \pm$ \\
& 0.07 & 0.18 & 0.12 & 0.09 & 0.11 & 0.09 & 0.03 & 0.05 & 0.06 & 0.08 \\
\hline
\end{tabular}

*Significant at $\mathrm{P}<0.05 \quad * *$ Significant at $\mathrm{P}<0.01$

Table 4: Effect of aflatoxin ( $1 \mathrm{mg} / \mathrm{kg} \mathrm{BW})$ gensing $(200 \mathrm{mg} / \mathrm{kg} \mathrm{BW})$ either alone or together on some liver and kidney functionss at 1st, 30 thand 60th days post medication for two months in male baladi rabbits $(n=5)$.

\begin{tabular}{|c|c|c|c|c|c|c|c|c|c|c|}
\hline \multirow{2}{*}{ parameter } & \multirow{2}{*}{$\begin{array}{c}\text { Healthy } \\
\text { rabbit }\end{array}$} & \multicolumn{3}{|c|}{$1^{\text {st }}$ days } & \multicolumn{3}{|c|}{$30^{\text {th }}$ days } & \multicolumn{3}{|c|}{$60^{\text {th }}$ days } \\
\cline { 3 - 11 } & & AF & GE & AF+GE & AF & GE & AF+GE & AF & GE & AF+GE \\
\hline AST & $41.36 \pm$ & $50.62 \pm$ & $42.52 \pm$ & $40.35 \pm$ & $48.62 \pm$ & $41.83 \pm$ & $40.73 \pm$ & $40.62 \pm$ & $41.68 \pm$ & $41.51 \pm$ \\
(U/L) & 1.76 & $2.46^{*}$ & 1.54 & 1.83 & $1.54^{*}$ & 1.05 & 2.62 & 1.63 & 1.48 & 1.89 \\
\hline ALT & $17.51 \pm$ & $25.93 \pm$ & $18.34 \pm$ & $16.03 \pm$ & $23.83 \pm$ & $17.92 \pm$ & $16.82 \pm$ & $19.65 \pm$ & $17.54 \pm$ & $17.48 \pm$ \\
(U/L) & 1.83 & $1.92^{*}$ & 0.68 & 0.93 & $1.06 *$ & 1.69 & 1.63 & 1.62 & 093 & 0.72 \\
\hline Alk.ph. & $63.12 \pm$ & $70.36 \pm$ & $63.61 \pm$ & $62.93 \pm$ & $68.93 \pm$ & $62.91 \pm$ & $63.04 \pm$ & $65.93 \pm$ & $63.06 \pm$ & $63.19 \pm$ \\
(I.U/ml) & 2.15 & $1.83^{*}$ & 2.08 & 1.82 & $1.71 *$ & 2.94 & 1.39 & 1.48 & 1.63 & 1.94 \\
\hline T. protein & $7.61 \pm$ & $5.21 \pm$ & $10.43 \pm$ & $7.20 \pm$ & $5.97 \pm$ & $9.57 \pm$ & $7.27 \pm$ & $7.30 \pm$ & $7.93 \pm$ & $7.60 \pm$ \\
(gm/dl) & 0.59 & $0.33^{* *}$ & $0.84 *$ & 0.57 & $0.23 *$ & $0.41 *$ & 0.76 & 0.44 & 0.40 & 0.60 \\
\hline
\end{tabular}

*Significant at $\mathrm{P}<0.05 \quad$ ** Significant at $\mathrm{P}<0.01$ 


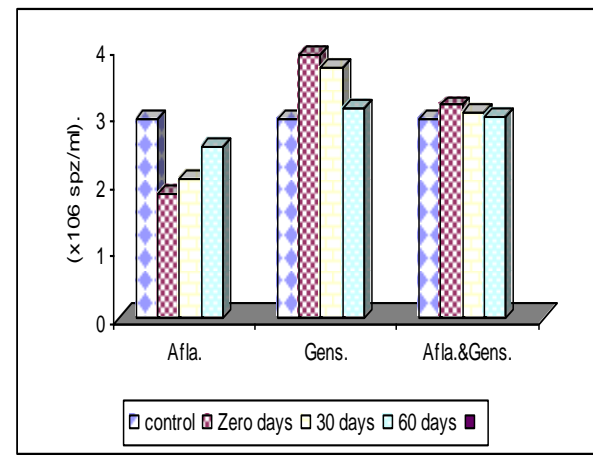

A) Sperm cell concentration

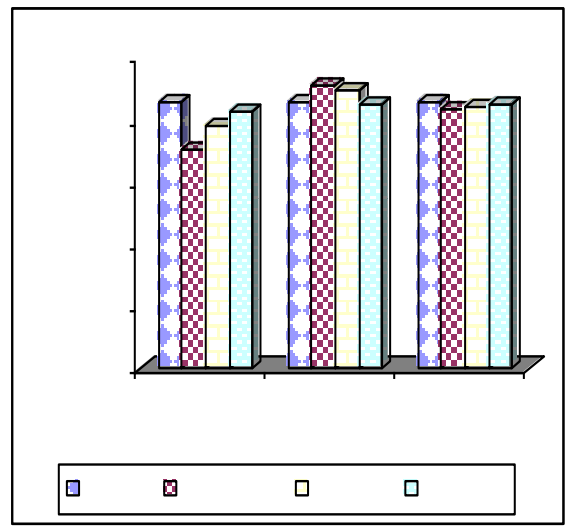

C) Alive sperm

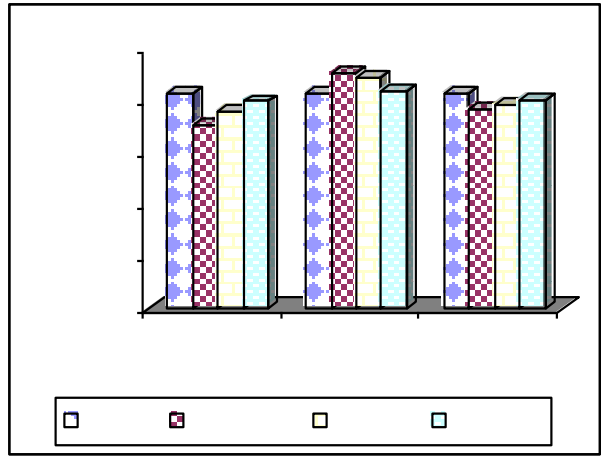

B) Sperm motility

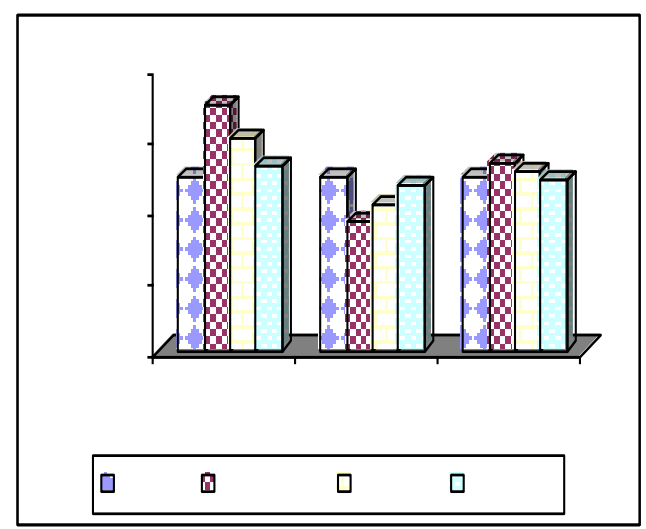

D) Total sperm abnormality

\section{DISCUSSION}

The obtained results revealed that aflatoxin caused highly significant decrease in the sperm cell concentration, sperm motility, alive sperm and induced significant increase in sperm abnormalities at $1^{\text {st }}$ and $30^{\text {th }}$ days post the use of aflatoxin. This effect was in accordance with that obtained by Baker and Greene (1987) who found that aflatoxin induced significant decrease in sperm cell concentration, progressive motility and alive percent of spermatozoa from $91.11 \%$ to $80.8 \%$. Another explanation were reported by Sahoo, et al. (1993) Who recorded that the decreased in sperm cell concentration, progressissive motility may be attributed to the disruption of spermatogenesis by chronic aflatoxicosis which is preceded and caused by the impairment of the leydig cell functions and the resultant drop in testosterone in the testis in rats. Ragheb and Sahar (2003) mentioned that the fertility of 
animals was vigorously reduced by aflatoxin consumption due to reduce in LH and FSH in male rats which are resposible for regulation of normal productivity of rats.

Significant decrease in the mean values of blood serum testosterone at $1^{\text {st }}$ and $30^{\text {th }}$ days post addition of aflatoxin for 60 days in the present study.Close similarity was seen between the finding and those obtained by Hassan et al. (2004) who found that aflatoxin induced decrease in testosterone hormone due to occurrence of oedema, fibrosis and local leydig cell.

Gensing treatment was able to increase the sperm cell concentration, sperm motility,alive sperm and testosterone hormone and induced significant decrease in sperm abnormalities at $1^{\text {st }}$ and $30^{\text {th }}$ days post treatment. The previous finding fit in with those previously reported by El-Sayed (2005) in rabbit. Moreover, this is supported by the findings of Yamammoto, et al. (1977) who said that gensing stim-ulated spermatogenesis in rat and rabbit testes and attributed to the stimulatory effect of ginsenosides on spermatogenesis to stimulation of DNA and protein synthesis in testis (Salvati et al. 1996). Ginsenosides may have an effect at different levels of the hypothalamus, pituitary, testis axis as increases hypothala-mic GnRH, pituitary gonad-otropines and testosterone levels in the blood in male rats (Fahim et al., 1982). Keeping with this line, Mkrtchyan et al. (2005) observed that gensing resulted in an increase in the number of spermatozoa, normal sperm motility and fertility indexes. The improvement in number of spermatozoa and motility in the present study may be due to the activation of spermatogenesis with gonadotropins hormones secreted from pituitray gland under the effect of GnRH (Nasr et al., 1994). This is supported by the findings of Sung et al., (2000) who said that Korean red gensing can improve the vascular endothelial dysfunction in patients with hypertension possibly through increasing NO.NO is a mediator that cause vascular smooth muscle fibers to relax thus resulting in vasodilatation,increasing the blood flow thus can improve the function of sexual organs (Huang, 1993). Decrease in sperm abnormalities in the present investigation may be due to the fact that androgen is essential for most stages of spermatogenesis and sperm production, furthermore, vitamin B12 (one component of gensing) participates in the synthesis of DNA, which conjugated with histon to form nucleoprotein of the sperm nucleus (Felsenfeld, 1978).

The present study illustrated that rabbits treated with gensing revealed significant increase in testosterone at $1^{\text {st }}, 30^{\text {th }}$ and $60^{\text {th }}$ days post 
medication. Close similarity was seen between the finding and those obtained by El-Sayed, (2005) who found that chronic administration of gensing produced a dose related increase in testosterone levels in male rats. This ultimately results in stimulation of steroidogenesis and production of testosterone (Hafez, 1987). In the current work, it has been found that aflatoxin induced significant decrease in weight of testis, seminal vesicle and prostate gland. The above mentioned results were supported by previous studies of Alexander (1978). The previous author mentioned that the development and maintenance of accessory sex organs and their secretion depend on androgen, Based on this idea the significant decrease in weight of accessory sex organs of rabbit feed on ration containing aflatoxin could be due to decrease in testosterone hormone level which recorded in the present study. Administration of gensing to rabbit induced non significant change in the sex organs weight in comparison to control group and these results run parallel with those obtained by Murphy et al. (1998) and El-sayed, (2005).

The present investigation revealed that the aminotransferases (AST-ALT) and alkaline phosphatase were significantly increased at $1^{\text {st }}$ and $30^{\text {th }}$ days post feeding rabbit on ration contain aflatoxin. Our results came inagreement with Arafa, et al. (2006). Mehta, et al. (1993) who stated that, aflatoxin induced hepatotoxicity and revealed a significant increase in the activity of plasma AST and ALT due to leakage of these enzymes into circulation in male rats. Another explanation for the increased activities of the liver enzyme occure due to altered permeability of hepatocytes (Roger et al., 1991).

Results of the present study revealed non significant effects on aminotransfe- rases (AST- ALT) and alkaline phosphatase concentrations at $1^{\text {st }}$ and $30^{\text {th }}$ days post administration of gensing in rabbits. These results agree with those of Lin, et al. (1995). They recorded that liver functions were unchanged after the use gensing extract in rats.

On the other context co-treatment of gensing and aflatoxin improve these adverse effects on the semen picture, testosterone and liver functions in comparison to control group. Rabbits treated with gensing and aflatoxin resulted in significant effect when compared with that of aflatoxin treated rabbit. This result can be explained by that reported by El-Saieed, (2003) who stated that, gensing exerted antioxidant effect by enhance the activity of the antioxidant enzymes.In addition, it has the ability to directly neutralize a number of toxic reactants and stimulate antioxidative enzymes. Also gensing inhibited 
the hepatic damage induced by toxin, Gensing also normalized liver functions and the serum liver enzyme activities (AST, ALT, Alkaline phosphatase) were not differ in compared with control group. These present finding suggested that gensing could protect hepatocytes membrane against oxidative stress induced by aflatoxin and hence prevent the libration of liver enzymes to the sera so it support liver functions. Okada and Zhang (1998) reported that gensing could protect cell membrane fatty acids from decomposition induced by free radicals so support the all functions of the animal body.Gensing also has a diuretic effect,produce light diarrhoea lead to decreease the amount of absorbed toxin and increase the level of glutathione (Reylnoids, 1991). Another suggestion is that gensing may repair the resources of some antioxidant enzymes as it increase the level of glutathione (El-Saieed, 2003).

In conclusion, from the present results it appears that aflatoxicosis in rabbits affects the male fertility and biochemical parameters. Therefore it is much better to control aflatoxicosis by using healthy feed free from aflatoxin and clean environ-ment rather than treatment of the rabbits.

\section{REFERENCES}

Ahmed, R.; Seth, V.; Pasha, S. and Banerjee, B. (2000): Influence of dietary ginger (Zingiber officinales Rosc) on oxidative stress induced by malathion in rats. Food Chem. Toxicol., 38: 443451.

Alexander, N. (1978): "Animals modeles for research on contraception and fertility". Harper and Row p. 106-326.

Arafa, M.; Mona M. Heta and Gehan H. El-Sakkar (2006): Field study on acute aflatoxicosis in goat with special reference to biochemical and histopathological changes. Kafr El-Sheikh Vet. Med. J. 4 (1)1047-1063.

Baker, D. and Greene, R. (1987): Coagulation defects of aflatoxin induced rabbits. Vet. Pathol. 24: 62-70.

Bearden, H. and Flaquary, J. (1980): Applied Animal Reproduction, Reston Publish- $4^{\text {th }}$ ed Co., Jnc. Reston, Virginia, chapter 2 PP. 158-160.

Chao, T. (1991): An outbreak of aflatoxicosis and boric acid poisoning in Malaysia: a clinicopathological study. J. Pathol. 164: 225237. 
Choi, Y.; Rha, K. and Cho, H. (1999): Effect of Korean red gensing on the rabbit corpus cavernsal smooth muscle. Int. J. Impot. Res. 10 (10) 37-43.

Chong, S. and Oberholzer, V. (1989): Gensing is there a use in clinical medicine. Postgrad, Med. J., 65 (76) 427-432.

Ciegler, A. and Bennet, J. (1980): Mycotoxins and mycotoxicosis. Bioscience 30: 512-520. Searle CE (Ed.) Chemical Carcinogens. ACS Mongraph, Wasington, DC: American Chemical Society. 1976.

Doumas, B.I. (1975): Abuiret colorimetric method for determination of a total protein. Clin Chem. 21: 1159 - 1166.

Eaton, D. and Groopman, J. (1994): The Toxicology of Aflatoxins Academic, Press, New York. chapter 6, pp 383-426.

El-Saieed, Eiman, M. (2003): Gensing reduce the hepatic damage induced by 2, 3, 7, 8. tetrachordibenzopdioxin in rats. J. Egypt Vet. Med. Ass.63 (1)205-216.

El-Sayed, Noura, A.H. (2005): Effect of gensing on male fertility in rabbit. M.D. Thesis Faculty. Science Zagazig University.

El-Seidy, I.; Mansour, M. and Agag, B. (2002): Protective effects of garlic and silyma-rin against free radicals induced by aflatoxin B1in rats. Egypt J. Comp. Clinic. Path .15 (1) 84-96.

Fahim, M.; Harman, M.; Clevenger, T. and Hafez, E. (1982): Effect of Panax gensing on testosterone level and prostate in male rats. Archies of Androl.; 8(4): 261-263.

Felsenfeld, G. (1978): Chromatin. Nature, 271: 115-129

Hafez, H. (1987): Reproduction in Farm Animals, Lea and Febiger, Philadelphia, 3th Ed. chapter 4, PP: 466-474.

Hassan, Manal, A.; Kamel, H. and Hassan, A. (2004): Clinicopathologial studies on caprine aflatoxiosis. Vet. Med. J. 52: 4: 535-550.

Hess, F.; Parent, R. and Cox, G. (1982): Reproduction study in rats on gensing extract G115. Food Chem Toxicol: 20: 189-192.

Huang, K. (1993): Herbs with multiple actions. In: The Pharmacology of Chinese herbs. Boca Raton, FL, CRC Press, chapter 8, PP. 2148..

Huang, R.C. (1999): The pharmacology of chines Herbs with multiple action CRC Press, Boea Raton, London, New York Washington chapter 1 pp17-51. 
Kamel, A. and Hoda, Lotfy, M. (2006): Effect of gensing extract on some hormonal immunological parameters in male new zealand white rabbits. Vet. Med. J. 54, 1: 153-165.

Kim, S.; Choi, J.; Wee, J. and Hwang, S. (2004): Panax gensing improves survival sperm quality in guinea pigs. Panminerva Med. J. 94 (4) $663-669$.

Kind, P. and king, E. (1954): Colorimetric determination of alkaline phosphatas activ-ity. J. Clin. Path. (7): 332-335.

Li, Q.; Duan, Z. and Zhang, J. (1997): Effects of age and ginsenoside on nitric oxide content and nitric oxide synthase activity of the cerebral cortex in rats. Acta. Pharm. Science 32: 251-257.

Lin, J.; Tsai, K.; Leu, S.Y. and Hsieh, N. (1995): Effects of gensing on the blood chemistry profile of dexamethasone-treated male rats. Am. J. Clin. Med. 23 (2)16-25.

Mehta, R.; Campbell, J. and Mueller, R. (1993): Acute hepatic response to aflatoxin B1in rats fed a methyl-deficient, minoaciddeficient diet.Cancer, Letter. 69(2)93-107.

Mkrtchyan, A.; Panosyan, V.; Panossian, A. and Wagner, H. (2005): Clinical study of Andrographis paniculata fixed combination Kan Jang versus gensing and valerian on the semen quality of healthy male subjects. Phytomedicine.12(6-7): 403-409.

Murphy, L.; Cadenaa, R.; Chanes, D. and Ferraro, J. (1998): Effect of American Gensing (Panax quinque foliun) on male copulatary behaviour in the rat. Physi. behaviour 64(4) 443-450.

Nasr, M.; Abdel-Ghaffar, A.; Agag, M. and Issa, S.S. (1994): Some trials for improv-ing fertility in bulls $2^{\text {nd }}$ VET. Med. Cong. Zag. 179186.

Okada, S. and Zhang, D. (1998): Gensing extract protects unsaturated fatty acids from decomposition caused by iron-mediated lipid peroxidase advances in gensing Res.Proceeding of the $7^{\text {th }}$ Interational Symposium on Gensing Seoul, Korea, 22-25

Peterson, S.; Horn, B. and Goto, T. (2001): Aspergillus bombycis, a new aflatoxigenic species and genetic variation in its sibling species, A. Nomius, Mycologia, 93, 68-73.

Petrie, A. and Watson, P. (1999): Statistics for Veterinary and Animal Science $1^{\text {st }}$ Ed. Chapter 3 PP 96-109 The Blackwell Science LTd, United Kingdom.

Ragheb, R. and Sahar, M. (2003): Influence of some mycotoxins on hormones regula-ting fertility and thyroid hormone in male rats. Egypt. J. Path. \& Clin. Path. 18(1)183-192 
Reitman, S. and Frankel, S. (1957): Acolorimetric method for determination of serum glutamic oxalacetic and glutamic pyruvic transaminase. Am. J. Clin. Path, (28) 56-60.

Reylnoids, J. (1991): Martindal. The extrapharmacopoeia. 29 ${ }^{\text {th }}$. chapter 6 PP1032-1065 The Pharmaceutical Press. London, UK.

Roger, C.; Leon, F.; Timoth, D. and Wilam, E. (1991): Dimination of aflatoxin toxicity growing lambs by transaminases. Am. J. Vet. Res. 52(1)152-156.

Sahoo, K.; Chattopadhyay, S.; Charan, K. and Sikdar, A. (1993): Pathology of exper- iment of aflatoxicosis in rabbits. Ind J. Anim. Sci 63: 268-73.

Salvati, G.; Genovesi, G. and Paolini, P. (1996): Effects of Panax Gensing C.A. Meyer saponins on male fertility. Panminerva Med. 38 (4): 249 - 254.

Samarajeewa, U.; Femando, S. and Ahmed, E. (1991): Inactivation of aflatoxin B1 in corn meal, copra meal and peanuts by chlorine gas treatment. Food Chem. 29, 41-54.

Sung, J.; Han, K.; Zo, J.; Park, H. and Ren, J. (2000): Effects of red gensing upon vasc-ular endothelial function in patientis with essential hypertension. Amer J.Clin. Med., 28: 205-206.

Verma, R. and Nair, A. (2001): Ameliorative effect of vitamin E on aflatoxin-induced lipid peroxidation in the testis of mice. Asian J. Androl., 3: 217-221.

Wilson, J. and Foster, D. (1992): "Williams text book of Endocrinology"1 ${ }^{\text {st }}$ Ed., chapter 6 pp 923-926 Saunders co., Philadelphia. Santener, S.

Yamamoto, M.; Kumatou, A. and Yamamura, Y. (1977): Stimulatory effect of panax gensing principales on DNA and protein synthesis in rat testis. Arzeimittel, Fertility, Dev., 9: 789-794. 